\title{
The effect of doubled CO2 and model basic state biases on the monsoon-ENSO system. l: Mean response and interannual variability
}

Article

Published Version

Turner, A.G., Inness, P.M. and Slingo, J.M. (2007) The effect of doubled $\mathrm{CO} 2$ and model basic state biases on the monsoon-ENSO system. I: Mean response and interannual variability. Quarterly Journal of the Royal Meteorological Society, 133 (626). pp. 1143-1157. ISSN 1477-870X doi: https://doi.org/10.1002/qj.82 Available at https://centaur.reading.ac.uk/859/

It is advisable to refer to the publisher's version if you intend to cite from the work. See Guidance on citing.

Published version at: http://dx.doi.org/doi:10.1002/qj.82

To link to this article DOI: http://dx.doi.org/10.1002/qj.82

Publisher: Royal Meteorological Society

All outputs in CentAUR are protected by Intellectual Property Rights law, including copyright law. Copyright and IPR is retained by the creators or other copyright holders. Terms and conditions for use of this material are defined in the End User Agreement. 


\section{www.reading.ac.uk/centaur}

\section{CentAUR}

Central Archive at the University of Reading

Reading's research outputs online 


\title{
The effect of doubled $\mathrm{CO}_{2}$ and model basic state biases on the monsoon-ENSO system. I: Mean response and interannual variability
}

\author{
A. G. Turner,* P. M. Inness and J. M. Slingo \\ Walker Institute, University of Reading, UK
}

\begin{abstract}
The impact of doubled $\mathrm{CO}_{2}$ concentration on the Asian summer monsoon is studied using a coupled oceanatmosphere model. Both the mean seasonal precipitation and interannual monsoon variability are found to increase in the future climate scenario presented. Systematic biases in current climate simulations of the coupled system prevent accurate representation of the monsoon-ENSO teleconnection, of prime importance for seasonal prediction and for determining monsoon interannual variability. By applying seasonally varying heat flux adjustments to the tropical Pacific and Indian Ocean surface in the future climate simulation, some assessment can be made of the impact of systematic model biases on future climate predictions. In simulations where the flux adjustments are implemented, the response to climate change is magnified, with the suggestion that systematic biases may be masking the true impact of increased greenhouse gas forcing. The teleconnection between ENSO and the Asian summer monsoon remains robust in the future climate, although the IndoPacific takes on more of a biennial character for long periods of the flux-adjusted simulation. Assessing the teleconnection across interdecadal timescales shows wide variations in its amplitude, despite the absence of external forcing. This suggests that recent changes in the observed record cannot be distinguished from internal variations and as such are not necessarily related to climate change. Copyright @ $\ 2007$ Royal Meteorological Society
\end{abstract}

KEY WORDS India; predictability; interdecadal variability; systematic error; El Niño

Received 11 August 2006; Revised 22 January 2007; Accepted 12 March 2007

\section{Introduction}

Climate change will have important repercussions for the monsoon climates of Southeast Asia for a number of reasons. Not only could increased greenhouse gas forcing affect the mean monsoon, but also further extremes of variability could have disastrous effects. More irregular or severe monsoon seasons could lead to water scarcity, food shortages and malnutrition during drought or an increase in water-borne disease after heavy rain, together with damage to local infrastructure.

Whilst making predictions of future monsoon behaviour is a key goal of climate change research, the findings do not always agree. May (2004) cites a number of different studies which give no overall indication of how the Asian summer monsoon will respond to increased greenhouse gas forcing. There are, however, a number of common themes. An increase in the land-sea meridional gradient of temperature in the Indian region may act to strengthen monsoon dynamics, as argued by Hu et al. (2000), or alternatively move the flow structure northward with no overall strengthening (Kitoh et al., 1997; Ashrit et al., 2003; May, 2004). Most previous

\footnotetext{
* Correspondence to: A. G. Turner, Walker Institute for Climate System Research, Department of Meteorology, University of Reading, PO Box 243, Earley Gate, Reading, RG6 6BB, UK.

E-mail: a.g.turner@rdg.ac.uk
}

work sees an increase in seasonal rainfall over India, ranging from just the peninsula ( $\mathrm{Hu}$ et al., 2000), to a varied response of increases in the north-west and far south (Ashrit et al., 2003), and an overall intensification of the mean pattern (Kitoh et al., 1997; May, 2004). The warmer Indian Ocean and enhanced low-level moisture convergence have been found to play a major role, allowing increased seasonal precipitation even in regions of weaker flow (e.g. Kitoh et al., 1997; Meehl et al., 2000; Ashrit et al., 2003).

In addition to the differential warming of land and sea, some studies such as Meehl and Washington (1996) notice a pattern of El Niño-like change in the equatorial Pacific (i.e. the east warming more than the west). Since El Niño is often associated with weak monsoons (e.g. Webster et al., 1998), this pattern of change may push the Indian monsoon toward drought conditions, via the atmospheric teleconnection. Indeed in a study of two coupled models under increasing $\mathrm{CO}_{2}$ conditions, Meehl et al. (2000) noted that El Niño-like warming in one model led to a smaller increase in seasonal mean precipitation when compared with the other model.

Aside from the mean response of the tropical Pacific, changes to ENSO variability would be likely to impact on the monsoon system. The understanding of future monsoon-ENSO behaviour can be helped by looking at current observations. Krishna Kumar et al. (1999) 
demonstrate that the inverse monsoon-ENSO relationship has broken down over recent decades. This breakdown is associated with a south-eastward shift in Walker circulation anomalies, reducing the anomalous subsidence over India and favouring normal monsoon conditions during El Niño. However, Torrence and Webster (1999) suggest that rather than a climatic shift, the weakened relationship is actually part of a series of variations on decadal timescales. They point to intervals of high (1875-1920, 1960-1990) and low (1920-1960) variance of the monsoon-ENSO system. During high periods, the system is highly coherent, lending itself to increased predictability. However, in experiments with an atmosphereonly GCM, Meehl and Arblaster (2003) demonstrate that even by fixing ENSO variability, monsoon variability can still increase under stronger greenhouse gas forcing due to changes in the basic state.

Although there are several large uncertainties contributing to the spread in future climate prediction (see, e.g. Ashrit et al., 2003), this study particularly relates to biases in the mean state in GCMs and their effect on monsoon prediction. Just as Sperber and Palmer (1996) noted the link between correct simulation of the climatological basic state in the tropics and accurate seasonal prediction of precipitation variability (as confirmed in Turner et al., 2005, hereafter TIS05), Federov and Philander (2000), amongst others, realized that such errors could have an enormous effect on future predictions. The effect of these errors will be assessed here through analysis of two future-climate integrations of the Met Office Unified Model HadCM3, using both the standard version of the model and the equatorial Indo-Pacific flux-corrected version (HadCM3IPFA) presented in TIS05. The experiments and data used are outlined in section 2 . Section 3 considers the effect of climate change on the mean state, whilst section 4 addresses monsoon variability. These results are related to ENSO changes in section 5, whilst the predictability of the monsoon via its teleconnection to the Pacific Ocean is considered in section 6. Conclusions are drawn in section 7 .

\section{Model details and observed datasets}

\subsection{The coupled model}

The GCM employed in this study is the fully coupled Unified Model, HadCM3, combining state-of-the-art atmosphere (Pope et al., 2000) and ocean (Gordon et al., 2000) components. HadCM3 was put to extensive use to provide climate change scenarios for the Intergovernmental Panel on Climate Change Third Assessment Report (IPCC, 2001). Multi-century integrations can be performed with no significant climate drift, without the use of flux adjustments (Johns et al., 2003).

The atmospheric component (HadAM3) is solved on a regular grid of $3.75^{\circ}$ longitude by $2.5^{\circ}$ latitude. Whilst the default vertical resolution is 19 levels, 30 levels are used in this study, as in TIS05, halving the layer thickness in the mid-troposphere to $50 \mathrm{mb}$. Inness et al.
(2001) showed this configuration to give an improved representation of intraseasonal variability in tropical convection, such as the Madden Julian Oscillation (MJO), and a subsequent study (Spencer and Slingo, 2003) found precipitation to respond more realistically to SST forcing, particularly El Niño. The oceanic component (HadOM3) has a uniform resolution of $1.25^{\circ}$ by $1.25^{\circ}$ with 20 levels in the vertical. The accurate simulation of the spatial structure and seasonality of the Asian summer monsoon (Martin et al., 2000) and of the monsoon trough (Johns et al., 2003), make HadCM3 well suited to this study.

\subsection{Model integrations}

This study uses results from the HadCM3 L30 control run (pre-industrial $\mathrm{CO}_{2}$ ) presented in TIS05. The model was initialized from an L19 integration of HadCM3, and an initial period of 10 years was discarded to allow any spin-up to the increased vertical resolution. As noted in TIS05, the L30 version of the model is also stable and its climatology is similar to that of the standard L19 version.

The HadCM3 $2 \times \mathrm{CO}_{2}$ experiment was initialized from an existing 150-year $2 \times \mathrm{CO}_{2}$ run, before which the carbon dioxide concentration had been ramped up at a rate of $1 \%$.year ${ }^{-1}$ for 70 years. Although it is unlikely to have achieved true equilibrium, the 150 -year stabilisation period prior to measurements being taken is in accordance with IPCC guidelines (see, e.g. Merryfield, 2006). The first 10 years of the new experiment were discarded as spin-up to L30, and the integration was continued for a further 100 years. This experiment is designed to look at the effect of climate change on the monsoon climate, the ENSO system and the teleconnection between them. The non-transient nature of the forcing allows the monsoonENSO system to be studied in detail, including its interdecadal variability.

HadCM3, as with all coupled models, contains systematic biases under control conditions (Inness et al., 2003; TIS05), as well as in future greenhouse forcing scenarios. However, there is no way of ascertaining whether the adjustments to counteract those errors would be the same in a future climate simulation. Consequently the same seasonal cycle of flux adjustments (as used in TIS05 to correct biases in the mean state) are applied to a future climate integration, known hereafter as HadCM3IPFA $2 \times \mathrm{CO}_{2}$. Heat fluxes are only fully applied in the equatorial band $\left( \pm 5^{\circ} \mathrm{N}\right)$ of the Indian and Pacific Oceans, and are ramped down to zero at $\pm 10^{\circ} \mathrm{N}$. Previous climate change experiments with older coupled GCMs kept the same seasonal cycle of anomalous fluxes as in their current climate (e.g. Collins, 2000a, using HadCM2). The objective of the HadCM3IPFA $2 \times \mathrm{CO}_{2}$ experiment is to explore the potential uncertainty caused by systematic biases rather than to necessarily give a better future prediction than HadCM3. The results of a 95-year integration of this model are presented.

The integrations will be referred to in the text as HadCM3 and HadCM3IPFA, both under $1 \times \mathrm{CO}_{2}$ and 
$2 \times \mathrm{CO}_{2}$ conditions. Neither of these integrations takes account of sulphate aerosol forcing.

\subsection{Observed datasets}

Observational and reanalysis datasets have been used in this study as a means of comparison with the current climate. Monsoon variability has been assessed using the ECMWF reanalysis dataset (ERA-40, Uppala et al., 2005) for the dynamical fields, the CMAP dataset (Xie and Arkin, 1997) and All-India Rainfall (AIR, Parthasarathy et al., 1994) for precipitation. Long-term El Niño behaviour has been assessed using HadISST data 1900-1999 (Rayner et al., 2003).

\section{The influence of climate change on the GCM basic state}

\subsection{HadCM3}

The effect of climate change (doubling $\mathrm{CO}_{2}$ concentration) on the mean summer climate of HadCM3 is shown in Figure 1. Firstly, considering surface temperatures, (Figures 1(a) and (d)) it is clear that warming has taken place across the whole of the Indo-Pacific sector. In the Pacific this is manifest as El Niño-like warming (i.e. +1.5 to $2{ }^{\circ} \mathrm{C}$ in the east, compared to $+1{ }^{\circ} \mathrm{C}$ in the west). This mean response amounts to a reduction in the zonal equatorial temperature gradient, and may lead to suppression of the monsoon following the arguments of Meehl et al. (2000). Such warming patterns were also noted by Timmermann et al. (1999) in their transient climate change integration, and by Ashrit et al. (2003) who found it to peak during boreal summer. However, in their review of the CMIP (Coupled Model Inter-comparison Project) integrations, Collins et al. (2005) found the most likely scenario was one of no El Niño- (or La Niña-) like climate change. Indeed, those models with the largest El Niñolike warming in future climate scenarios were generally those featuring poorly simulated present day ENSO variability. As an exception, HadCM3 was found to exhibit realistic ENSO variability when compared to other coupled models (Latif et al., 2001). Such a warming pattern on the surface complements changes in equatorial subsurface waters, where the vertical temperature gradient is enhanced, amounting to an intensification of the thermocline, and deepening in the east (not shown). Collins (2000b) attributes the increased vertical temperature gradient at $2 \times \mathrm{CO}_{2}$ to the slow penetration of heat into the ocean. Once warmed, the upper levels become stable due to their buoyancy, inhibiting mixing and warming at depth.

Figure 1(d) shows land regions have warmed to a greater degree than the ocean. Given that this experiment undergoes fixed $\mathrm{CO}_{2}$ forcing, the explanation is not as simple as the much larger heat capacity of water. Sutton et al. (2007) have suggested that, assuming the anomalous surface climate forcing is evenly distributed over land and sea, the upward energy flux required to balance this will consist of a greater latent heat flux over the ocean. Thus, temperatures over the land are more easily raised as there is less potential for increased evaporation, leading to a land-sea warming contrast. Relatively more warming occurs in the northern hemisphere due to the uneven distribution of the continents, as noted by, e.g. Timmermann et al. (2004). This differential in surface warming has led to an increase in the land-sea meridional gradient of temperature in the Indian region, which may act to strengthen the monsoon dynamics (Hu et al., 2000). However the lower tropospheric winds $(850 \mathrm{hPa})$ shown in Figures 1(b) and (e) suggest that increased greenhouse forcing has affected the mean winds in only a few localities. The Pacific trade winds at about $5^{\circ} \mathrm{N}$ are approximately $1 \mathrm{~ms}^{-1}$ weaker in the region $150^{\circ} \mathrm{E}-150^{\circ} \mathrm{W}$, consistent with the El Niño-like surface warming. Over the Indian Ocean, the flow at lower levels is more easterly just west of Sumatra, i.e. weaker across the south Bay of Bengal. It is difficult to relate this weakening to Pacific El Niño-like warming given that it is accompanied by stronger flow $\left(+1 \mathrm{~ms}^{-1}\right)$ in the northern Arabian Sea and the north of India. This amounts to a slight northward shift of the monsoon flow structure, attributed to the increased meridional heating gradient by May (2004).

The anomalous easterlies out of Sumatra are part of a small anomalous anticyclone in the southern hemisphere, leading to local drying (of up to $3 \mathrm{~mm}^{-d_{a y}}{ }^{-1}$ in Figure 1(f)). Significant increases (at the $95 \%$ level using a student t-test) in mean precipitation are noted in the main summer ITCZ and SPCZ bands across the Pacific Ocean. The northward displacement of the ITCZ is related to the preferential warming of the northern hemisphere, displacing the thermal equator in HadCM3 (Johns et al., 2003). Considering the Asian Summer Monsoon region, it is clear that the mean precipitation during the summer season has increased by between $0.5 \mathrm{~mm} \cdot \mathrm{day}^{-1}$ in the northern states and at the tip of peninsula India, and $2 \mathrm{~mm} \cdot \mathrm{day}^{-1}$ in the north-eastern Bay of Bengal, Bangladesh and Myanmar. The South China Sea also sees significant increases of this magnitude.

The response of HadCM3 to $2 \times \mathrm{CO}_{2}$ compares well with other studies. In agreement with work cited in the introduction (Kitoh et al., 1997; Meehl et al., 2000; Hu et al., 2000; Ashrit et al., 2003; May, 2004), HadCM3 shows an overall increase in monsoon precipitation. However the spatial pattern of change is most similar to that found by Meehl and Arblaster (2003) using the Parallel Climate Model (PCM), although they found no drying south-west of Sumatra. Rather than the increased meridional temperature gradient, they attribute the increase in mean south Asian monsoon rainfall to the warmer Indian Ocean providing increased moisture, as in an earlier study by Meehl et al. (2000). Enhanced moisture convergence is also cited as the principal mechanism providing increased precipitation by Kitoh et al. (1997) and Ashrit et al. (2003). In this modelling framework, measurements of surface evaporation change between $1 \times \mathrm{CO}_{2}$ and $2 \times \mathrm{CO}_{2}$ are minimal (not shown), demonstrating that precipitation increases in HadCM3 are due 

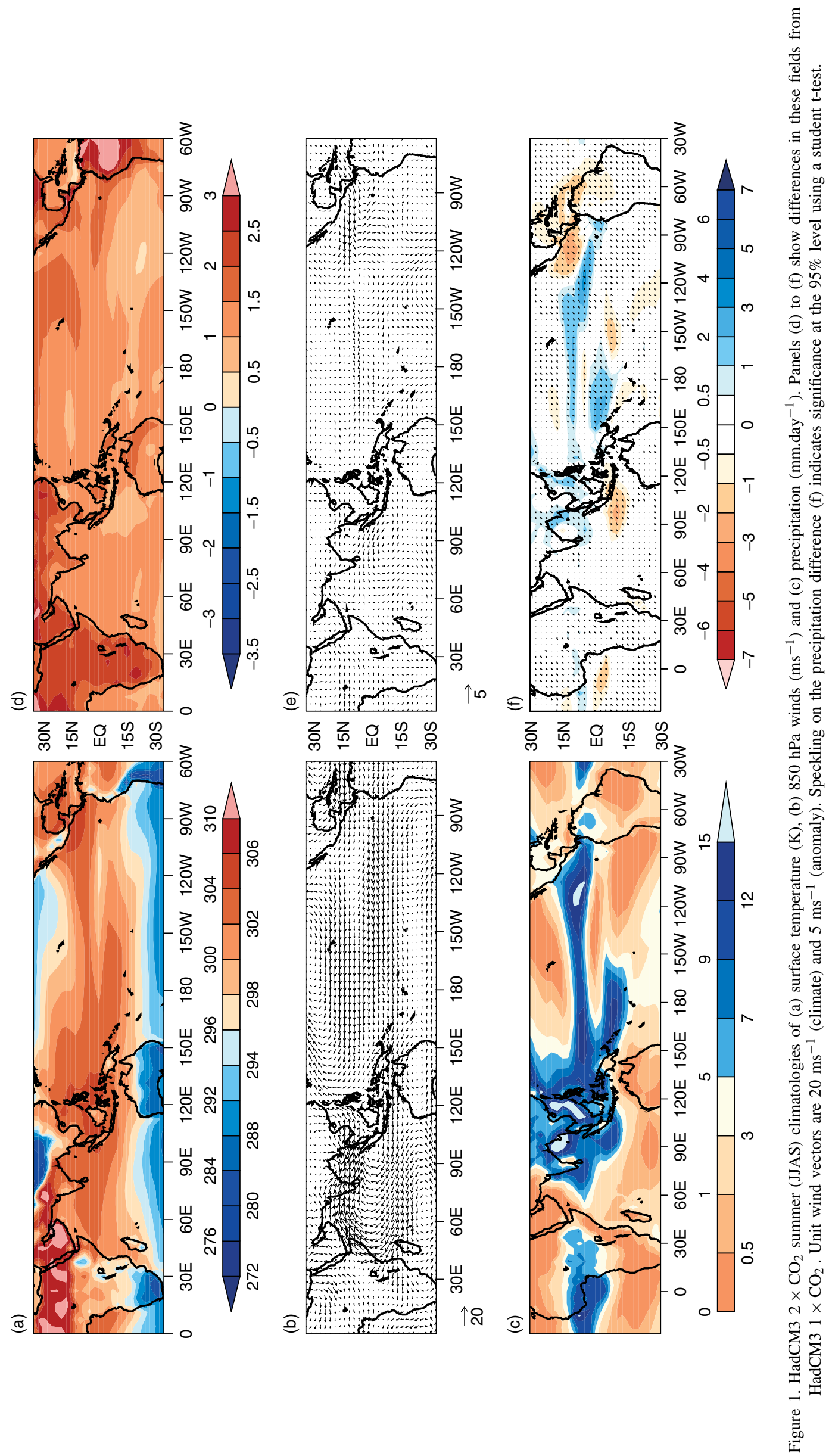
to increased moisture convergence. The small response of the monsoon circulation to increased $\mathrm{CO}_{2}$ suggests non-dynamical causes for the increased moisture (Ashrit et al., 2003), and increased atmospheric water content over the northern Indian Ocean in HadCM3 $2 \times \mathrm{CO}_{2}$ (not shown) confirms this.

Using SRES transient simulations in HadCM3, Johns et al. (2003) also noted significantly wetter conditions for South Asia during summer, although a weaker monsoon response was found when sulphate forcing was incorporated into the B2 scenario, consistent with the cooling effects of aerosols. The inclusion of aerosol forcing was also found to partially counter the effects of increased $\mathrm{CO}_{2}$ on monsoon precipitation in a study by Ashrit et al. (2003), highlighting the uncertainty involved in projections of future climate.

\subsection{HadCM3IPFA}

Figure 2 shows the mean summer climate of the HadCM3IPFA $2 \times \mathrm{CO}_{2}$ integration $(\mathrm{a}-\mathrm{c})$ and its differences with HadCM3IPFA $1 \times \mathrm{CO}_{2}(\mathrm{~d}-\mathrm{f})$. Looking at the summer (JJAS) surface temperature difference in Figure 2(d), it is clear that the flux-corrected version of the model shows a similar response pattern to the standard model (Figure 1(d)), with increased warming over land regions and a preferential response in the East Pacific, reducing the east-west SST gradient. This is accompanied by vertical intensification of the thermocline and deepening in the east, as in HadCM3 (not shown).

The surface wind response shown in Figure 2(e) indicates a more marked pattern of change in the Indian monsoon region than in HadCM3 (Figure 1(e)), with the increase in the low-level flow over the northern Arabian Sea being more pronounced. There is increased convergence at $850 \mathrm{hPa}$ in the warmer eastern equatorial Pacific, which aids the increased precipitation along the ITCZ noted in Figure 2(f). The magnitude of rainfall increase in the tropical convergence zone of the Pacific is much larger with flux adjustments, reaching almost $5 \mathrm{~mm} \cdot \mathrm{day}^{-1}$ with climate change. The region of drying in HadCM3 west of Sumatra (Figure 1(f)) is slightly larger and farther west, this is likely related to the stronger anticyclone there. In the Indian region, the same response pattern is represented in both versions of the model, although here it is stronger, especially in the north of India, the north Bay of Bengal, Bangladesh and southcentral China.

The patterns of change are very similar in all three fields shown in Figures 1 and 2, although the fluxadjusted version seems to exhibit a stronger response to climate change. The only major difference lies in the precipitation response, where the standard model (Figure 1(f)) shows a wetter ITCZ and SPCZ, whereas HadCM3IPFA (Figure 2(f)) indicates increased precipitation in a band from the SPCZ in the west across to the central ITCZ, and further increases in a band in the central Pacific north of the equator. This may be related to the spatial pattern of applied flux adjustments
(TIS05 Figure 2), which preferentially increases SST in the central equatorial Pacific. Against a background of the warmer climate, this provides warmer mean SSTs and hence increased precipitation due to the non-linear nature of the Clausius-Clapeyron relationship.

In Figure 3, the effects of flux adjustments alone at $2 \times \mathrm{CO}_{2}$ are considered and can be compared to those at $1 \times \mathrm{CO}_{2}$ (see TIS05, Figure 3). The patterns of mean surface temperature change forced by equatorial flux adjustments are qualitatively similar at $1 \times \mathrm{CO}_{2}$ and $2 \times \mathrm{CO}_{2}$, reflecting the largely linear response of the ocean surface to identical heat flux anomalies. The wind response is also similar, although the reduction in the monsoon jet over the Arabian Sea is less obvious. This is likely to be because the temperature changes induced by the anomalous fluxes are taking place against a warmer background state than at $1 \times \mathrm{CO}_{2}$, so their influence on the absolute meridional temperature gradient across the Arabian Sea and Indian subcontinent will be less marked.

In summary, it is possible that the systematic bias in tropical ocean temperatures (which is predominantly cold in the central Pacific and too warm around the Maritime Continent) causes HadCM3 to underestimate the effects of increased greenhouse gas forcing. These biases in the basic state may also propagate through to the interannual variability, as described in TIS05, and thus lead to greater uncertainty in the predictability of monsoon systems in the future climate.

\subsection{Quantifying precipitation changes over India}

Now that both future-climate integrations have been introduced, we can make a quantitative estimate of the precipitation increase over the Indian region. First we consider the Indian land surface grid points, as defined by Gadgil and Sajani (1998). These are 27 land-surface grid points within $10-27.5^{\circ} \mathrm{N}, 71.25-86.25^{\circ} \mathrm{E}$, where coordinates refer to grid point centres. The summer monsoon season (JJAS) daily rainfall totals are shown in Table I, together with differences to the $1 \times \mathrm{CO}_{2}$ scenarios. The observed values are taken from 1979-2004 CMAP data, bilinearly interpolated to the model grid prior to calculation. Increased greenhouse gas forcing causes an increase in monsoon season precipitation, between +3.5 and $+12.7 \%$ depending on model version, the flux adjustments having a very significant impact. This reinforces the suggestion that systematic errors in HadCM3 may be masking the true impact of increased $\mathrm{CO}_{2}$ concentration. It is also interesting to note the effect of flux adjustment alone for a given greenhouse gas concentration. The excessive summer monsoon rainfall in HadCM3 (described in TIS05) is reduced by $20.5 \%$ after flux adjustment. Removing the same systematic errors has a smaller but still significant effect in the future climate $(-13.5 \%)$.

For comparative purposes, and to give an idea of the broader behaviour, seasonal rainfall has also been measured over a larger region covering India, the Bay of Bengal, Arabian Sea and the Himalayas as well as 

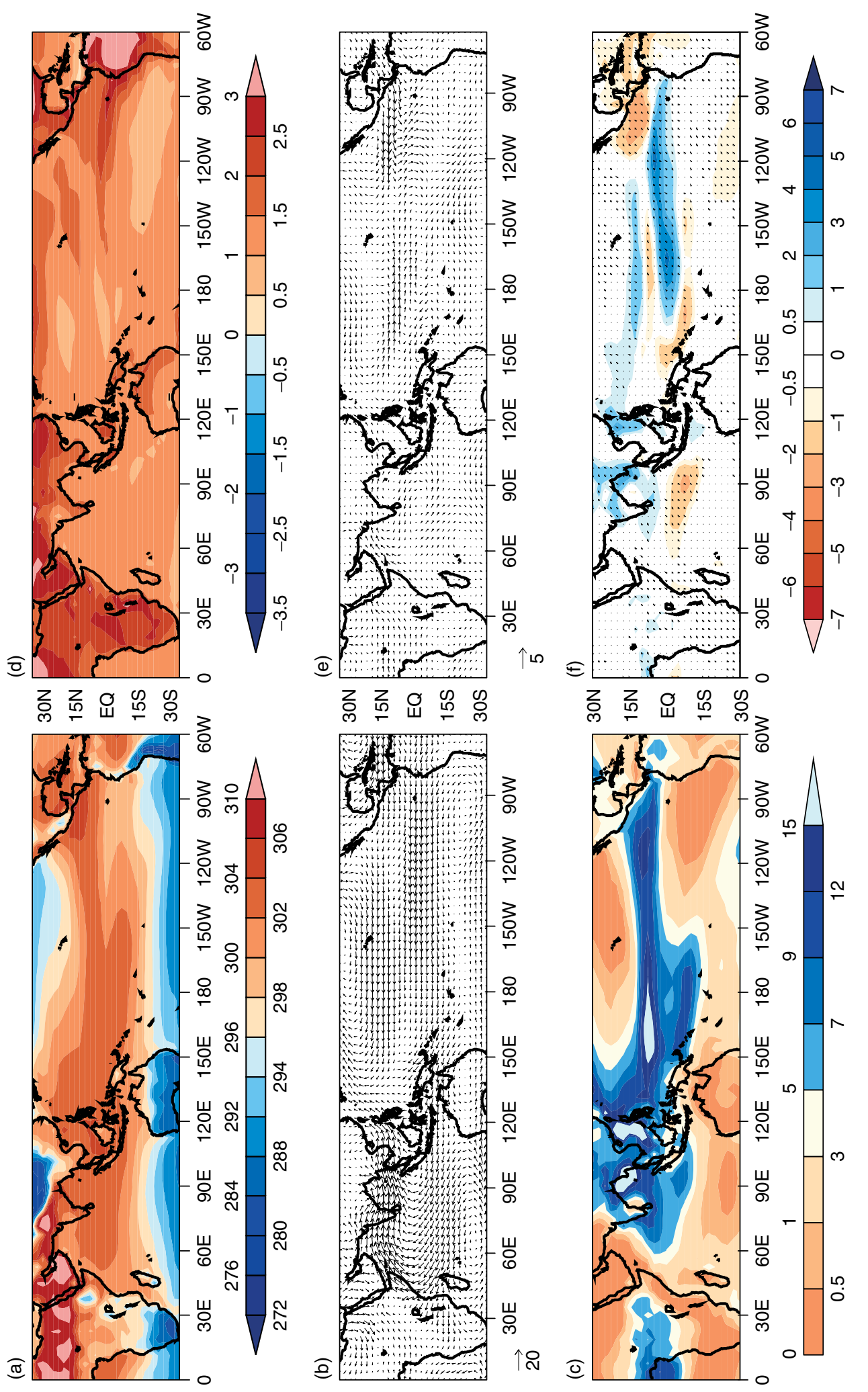

윰

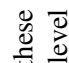

$\exists$ 吕

\&

式

क

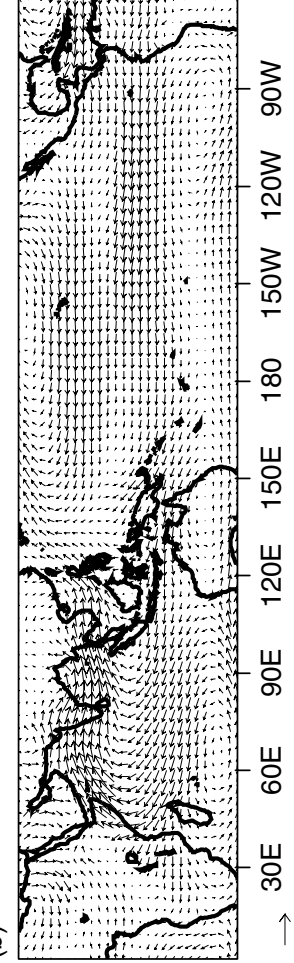


(a)

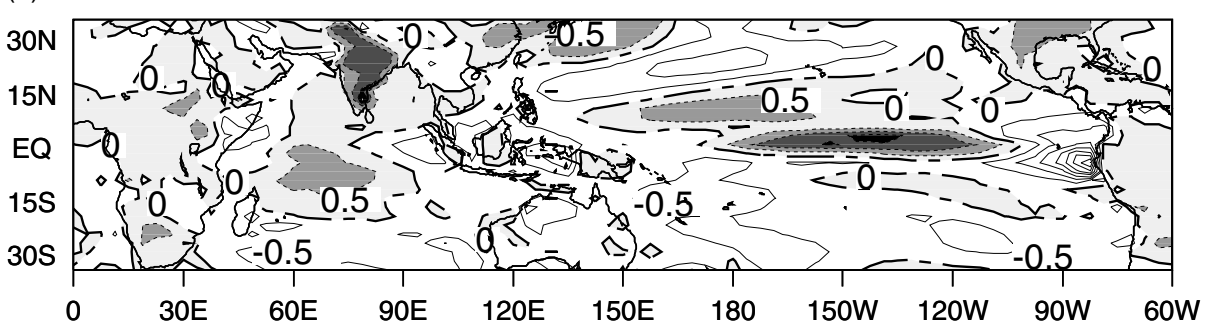

(b)

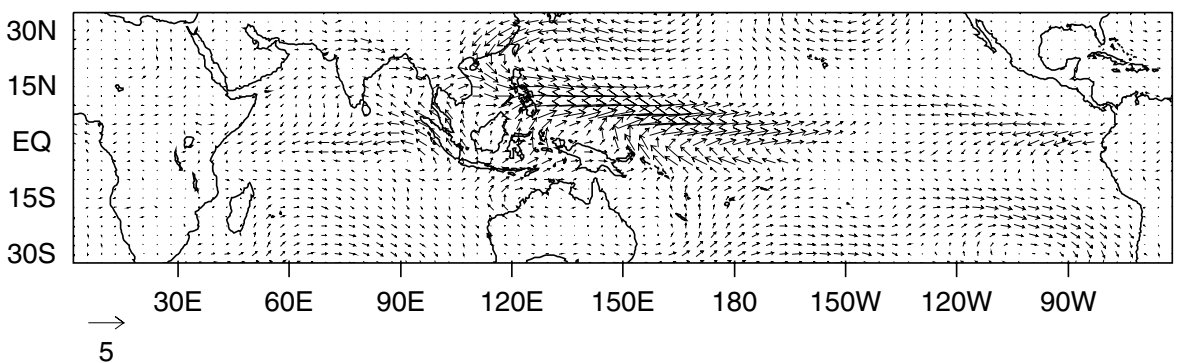

(c)

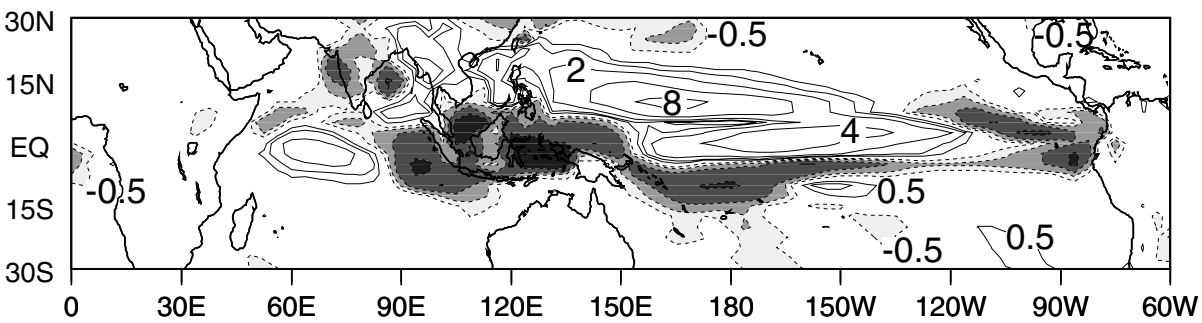

Figure 3. Response of the mean summer (JJAS) climate to flux adjustments at $2 \times \mathrm{CO}_{2}$ for (a) surface temperature (K), (b) $850 \mathrm{hPa}$ winds $\left(\mathrm{ms}^{-1}\right)$ and (c) precipitation $\left(\mathrm{mm} \mathrm{day}^{-1}\right)$. Temperature contour interval is $0.5 \mathrm{~K}$, positive contours are shaded and dashed, negative contours are solid. Unit wind vector is $5 \mathrm{~ms}^{-1}$. Negative precipitation contours are shaded and dashed, positive precipitation contours are ful. Precipitation contours are at $\pm 1248 \mathrm{~mm} \mathrm{day}^{-1}$.

Table I. Daily rainfall totals $\left(\mathrm{mm} \cdot \mathrm{day}^{-1}\right)$ during the JJAS season over the Indian land surface, as defined by Gadgil and Sajani (1998).

\begin{tabular}{lcccc}
\hline $\mathrm{CO}_{2}$ & CMAP & HadCM3 & HadCM3IPFA & $\Delta$ rain $_{\mathrm{FA}}$ \\
\hline Observed & 4.60 & - & - & - \\
$1 \times \mathrm{CO}_{2}$ & - & 4.29 & 3.41 & $-20.5 \%$ \\
$2 \times \mathrm{CO}_{2}$ & - & 4.44 & 3.84 & $-13.5 \%$ \\
$\Delta$ rain $_{\mathrm{CO} 2}$ & - & $+3.5 \%$ & $+12.7 \%$ & - \\
\hline
\end{tabular}

other parts of Southeast Asia. The region is $5-40^{\circ} \mathrm{N}$, $60-100^{\circ} \mathrm{E}$, after Meehl and Arblaster (2003), who noted a change in rainfall of $+9 \%$ during JJA when carbon dioxide concentrations were doubled. The response to increased greenhouse gas concentration in HadCM3, as shown in Table II, is +5.2 to $+8.5 \%$ for JJAS $(+4.6$ to $+8.4 \%$ for JJA, not shown), and therefore consistent with the results of Meehl and Arblaster (2003). Illustrating the difficulty in modelling monsoon precipitation, HadCM3 is seen to overestimate monsoon rainfall over the broad region despite underestimating it over the Indian land surface.
Table II. Daily rainfall totals $\left(\mathrm{mm} \cdot \mathrm{day}^{-1}\right)$ during the JJAS season over the $5-40^{\circ} \mathrm{N}, 60-100^{\circ} \mathrm{E}$ region after Meehl and Arblaster (2003).

\begin{tabular}{lcccc}
\hline $\mathrm{CO}_{2}$ & CMAP & HadCM3 & HadCM3IPFA & $\Delta$ rain $_{\mathrm{FA}}$ \\
\hline Observed & 4.79 & - & - & - \\
$1 \times \mathrm{CO}_{2}$ & - & 5.17 & 4.76 & $-7.9 \%$ \\
$2 \times \mathrm{CO}_{2}$ & - & 5.44 & 5.17 & $-4.9 \%$ \\
$\Delta$ rain $_{\mathrm{CO} 2}$ & - & $+5.2 \%$ & $+8.5 \%$ & - \\
\hline
\end{tabular}

\section{Climate change and monsoon variability}

As well as changes in the mean climate, future variability of the monsoon will be of critical importance. Any increase in the spread around the mean will require societies to become increasingly adaptable. Increased monsoon variability in a warmer climate is a common finding of modelling studies, and was first noted by Meehl and Washington (1993) in an early-coupled model. In more recent studies at higher resolution, Kitoh et al. (1997) and May (2004) found increased monsoon variability in transient and $2 \times \mathrm{CO}_{2}$ experiments respectively. As well as All-India Rainfall, the dynamical monsoon index (DMI, 


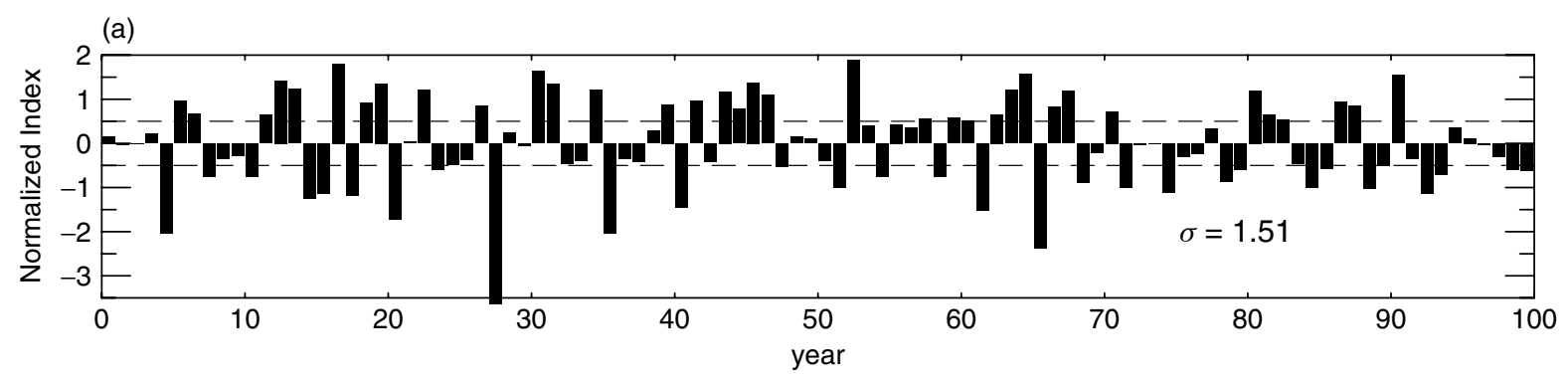

(b)

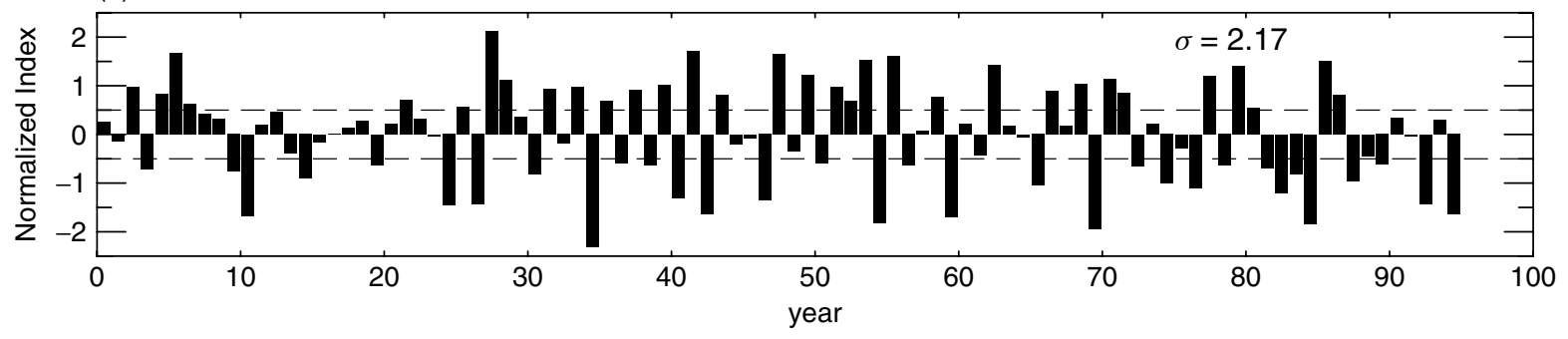

Figure 4. The summer (JJAS) dynamical monsoon index as described in Equation (1) for (a) HadCM3 $2 \times \mathrm{CO}_{2}$ and (b) $\mathrm{HadCM}_{3} \mathrm{IPFA}_{2} \times \mathrm{CO}_{2}$. Note that the years in the two model runs are entirely independent.

Webster and Yang, 1992) has been used as a measure of the interannual variability of the monsoon over the broad South Asia region. The index is defined as the anomalous zonal windshear during summer (JJAS),

$$
\mathrm{DMI}=\overbrace{\left(U_{850}-\bar{U}_{850}\right)-\left(U_{200}-\bar{U}_{200}\right)},
$$

where the overbrace indicates averaging over the 40$110^{\circ} \mathrm{E}, 5-20^{\circ} \mathrm{N}$ region. We can compare the two measures of monsoon strength in summer by taking their correlation. Table III shows that increasing greenhouse gas concentration results in increased coupling between the modelled monsoon wind strength and precipitation. This suggests that in future scenarios the DMI is increasingly useful as an indicator of monsoon strength, although the reason for this is unclear.

The DMI is shown in Figure 4 for both versions of the model under $2 \times \mathrm{CO}_{2}$ conditions. A striking feature is the pronounced biennial monsoon behaviour in the HadCM3IPFA $2 \times \mathrm{CO}_{2}$ integration, i.e. a weak monsoon being followed by a strong monsoon and vice versa. This tendency of the monsoon in HadCM3IPFA $2 \times \mathrm{CO}_{2}$ to exhibit tropospheric biennial oscillation (TBO) behaviour (as described in Meehl (1997) and Ogasawara et al. (1999) amongst others) will be studied in more detail in part II of this paper (Turner et al., 2007). Both models

Table III. Correlation between summer (JJAS) dynamical monsoon index and Indian rainfall for both models and the reanalysis/observations.

\begin{tabular}{lccc}
\hline $\mathrm{CO}_{2}$ & HadCM3 & HadCM3IPFA & ERA-40/AIR \\
\hline Observed & - & - & 0.55 \\
$1 \times \mathrm{CO}_{2}$ & 0.25 & 0.47 & - \\
$2 \times \mathrm{CO}_{2}$ & 0.40 & 0.58 & - \\
\hline
\end{tabular}

show strong extremes. The probability density functions of the data (not shown) indicate reduced occurrence of conditions close to the mean when compared to integrations at $1 \times \mathrm{CO}_{2}$. This result is independent of the index used to measure monsoon strength.

Table IV summarizes the interannual standard deviation of the DMI, which reaches $1.51 \mathrm{~ms}^{-1}$ in HadCM3 $2 \times \mathrm{CO}_{2}$. This represents an increase of nearly a quarter over the equivalent $1 \times \mathrm{CO}_{2}$ integration, but is still lower than that for the ERA-40 reanalysis. Using flux adjustments, variability is also increased, as in the $1 \times \mathrm{CO}_{2}$ scenarios of TIS05, but the response to $2 \times \mathrm{CO}_{2}$ is not so marked. Consideration of precipitation variability measured over the Indian land surface (defined earlier) yields consistent increases for doubled $\mathrm{CO}_{2}$, but apparently little change when flux adjustments are applied. When considered as a percentage of the seasonal total rainfall however, (120 days $\times$ daily rate values in Table I) precipitation variability is still increased with flux adjustments.

The effect of both flux adjustments and $\mathrm{CO}_{2}$ doubling on monsoon variability is one of more frequent and stronger extremes. Further evidence for this can be seen in the following composite analysis, using the DMI to delineate strong and weak monsoons over the broad South Asia region.

Table IV. Interannual standard deviation of summer monsoon statistics: DMI (AIR). Units are $\mathrm{ms}^{-1}(\mathrm{~mm})$. Comparisons are with ERA-40 (CMAP) over 1958-1997 (1979-2004) periods.

\begin{tabular}{lccc}
\hline $\mathrm{CO}_{2}$ & HadCM3 & HadCM3IPFA & ERA-40/CMAP \\
\hline Observed & - & - & $1.60(84.3)$ \\
$1 \times \mathrm{CO}_{2}$ & $1.22(111.0)$ & $2.05(109.8)$ & - \\
$2 \times \mathrm{CO}_{2}$ & $1.51(126.0)$ & $2.17(129.1)$ & - \\
\hline
\end{tabular}


A composite difference of strong (DMI $>0.5 \sigma)$ and weak $(<-0.5 \sigma)$ summer monsoon seasons (JJAS) is shown for precipitation and $850 \mathrm{hPa}$ winds in Figure 5, and for surface temperature in Figure 6. The wind difference pattern for HadCM3 $2 \times \mathrm{CO}_{2}$ is similar to that at $1 \times \mathrm{CO}_{2}$ (see TIS05 Figure 7), although the cyclonic anomaly over the Bay of Bengal, the monsoon flow, and the anomalous inflow into the Maritime Continent are all stronger. Associated with these circulation patterns are precipitation increases, dynamically strong monsoons now being wetter than weak monsoons by $2 \mathrm{~mm} \cdot \mathrm{day}^{-1}$ in the west of India, and up to $3 \mathrm{~mm} \cdot \mathrm{day}^{-1}$ in the Bay of Bengal, whilst the Maritime Continent and the Indian Ocean to the west of Sumatra receive a further $4 \mathrm{~mm} \cdot \mathrm{day}^{-1}$. The drier region associated with the anomalously strong Pacific trades is down by $6 \mathrm{~mm} \cdot \mathrm{day}^{-1}$ during strong monsoon years. The West African monsoon winds are noticeably stronger in HadCM3 $2 \times$ $\mathrm{CO}_{2}$ during strong Asian summer monsoon years. For HadCM3IPFA $2 \times \mathrm{CO}_{2}$ (Figure 5b), as at $1 \times \mathrm{CO}_{2}$, the flux adjustments have caused an increase in variability in the Indo-Pacific basins, although the same systematic patterns are evident as in the standard version of HadCM3. Strong Asian summer monsoons are now even wetter over the Arabian Sea, India, and the Bay of Bengal. The anomalous cyclonic flow just south-west of Sumatra means that strong monsoon summers are $6 \mathrm{~mm} \cdot \mathrm{day}^{-1}$ wetter there than weak summers. There is now evidence of additional precipitation in the Gulf of Guinea, part of the West African monsoon, coinciding with the anomalous westerlies across the continent.

The monsoon difference composite for surface temperature (Figure 6) shows increased variability in the central equatorial Pacific when compared to $1 \times \mathrm{CO}_{2}$ (TIS05 Figure 8): a $1.5^{\circ} \mathrm{C}$ range in $\mathrm{HadCM} 32 \times \mathrm{CO}_{2}$ and $4{ }^{\circ} \mathrm{C}$ in HadCM3IPFA $2 \times \mathrm{CO}_{2}$. This suggests increased coupling between the monsoon and ENSO at $2 \times \mathrm{CO}_{2}$. In the Indian Ocean, flux adjustments cause strong monsoons to be increasingly associated with warm SSTs west of Sumatra, the difference rising from $1.2^{\circ} \mathrm{C}$ in $\mathrm{HadCM} 3$ to $1.7^{\circ} \mathrm{C}$ in HadCM3IPFA. This enhanced coupling between the monsoon and Indian Ocean will be examined in more detail in part II.

\section{ENSO variability and climate change}

Before considering monsoon predictability, interannual variability in the tropical Pacific, to which variations in the monsoon are tied (e.g. Torrence and Webster, 1999), will be discussed. Guilyardi (2006) studied ENSO characteristics of the multi-model ensemble assessed for the IPCC AR4 (these are made available through the WCRP CMIP3 multi-model dataset archived at PCMDI and are hereafter referred to as the IPCC AR4 integrations). He noted that those models which featured the most realistic mixture of mechanisms when compared to observations displayed an increase in ENSO amplitude in future greenhouse warming scenarios. By considering how models represent different feedback loops in the generation of El Niño-La Niña anomalies, van Oldenborgh et al. (2005) demonstrate slight increases, decreases and null responses in ENSO variation, although none lie outside the range of observed decadal variability. Merryfield (2006) also found no consensus on ENSO amplitude change in the IPCC AR4 integrations.

One suggested mechanism for ENSO amplitude change lies in the vertical intensity of the thermocline. Timmermann et al. (1999) found much stronger ENSO variability when the ECHAM4/OPYC3 coupled model was subject

(a)

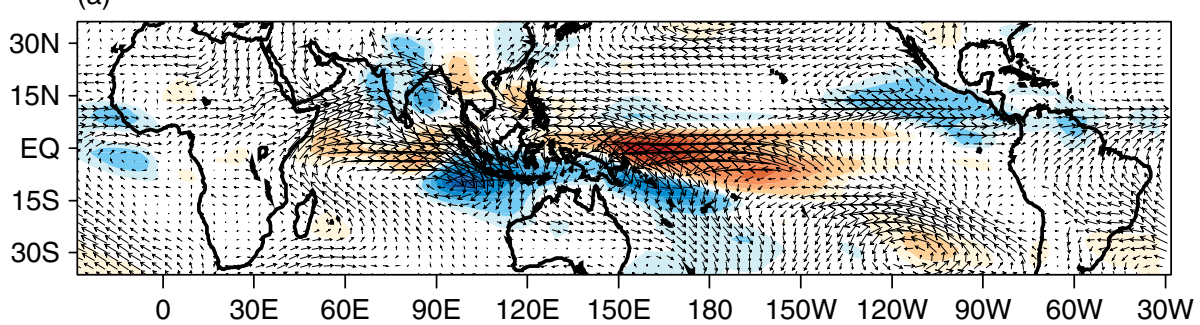

(b)

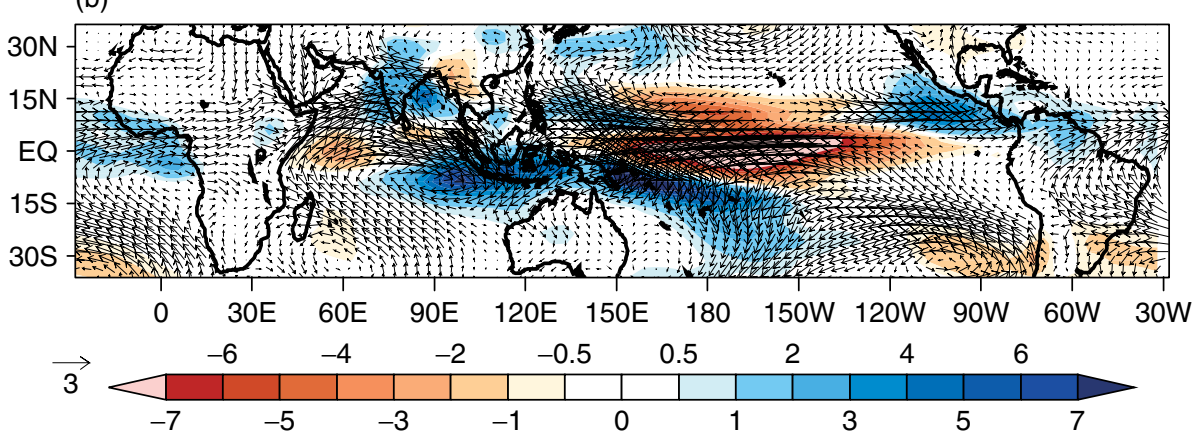

Figure 5. Strong minus weak year composite difference plots of summer (JJAS) lower tropospheric ( $850 \mathrm{hPa}$ ) winds and precipitation for (a) $\mathrm{HadCM} 32 \times \mathrm{CO}_{2}$ and (b) HadCM3IPFA $2 \times \mathrm{CO}_{2}$. Unit wind vectors are $3 \mathrm{~ms}^{-1}$. 
(a)

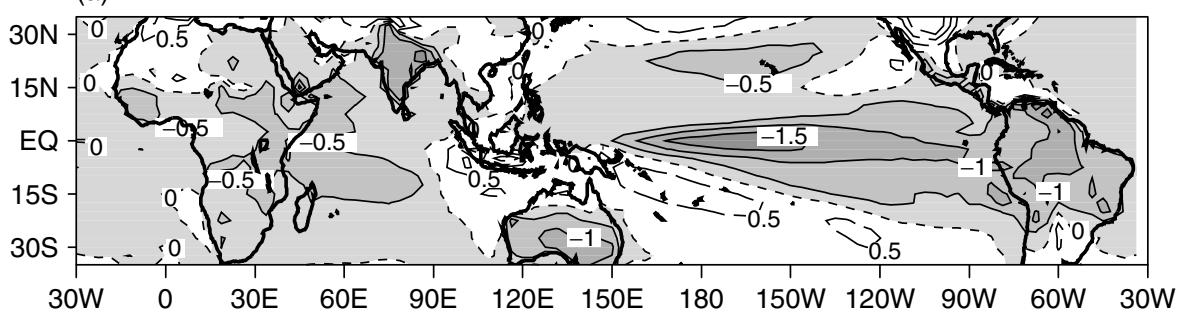

(b)

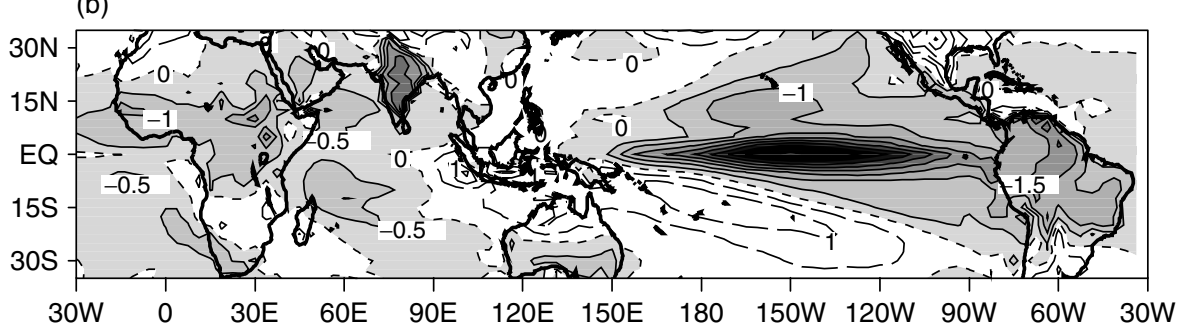

Figure 6. Strong minus weak year composite difference plots of summer (JJAS) surface temperature (K) for (a) $\mathrm{HadCM}_{3} 2 \times \mathrm{CO}_{2}$ and (b) HadCM3IPFA $2 \times \mathrm{CO}_{2}$. Negative differences are shaded whilst dashed contours show positive differences. Contour interval is $0.5 \mathrm{~K}$.

to IS92a forcing, as did Collins (2000a) in HadCM2, attributable to the increased vertical temperature gradient. This makes temperatures on the ocean surface more prone to variation via thermocline movements. Using similar reasoning, Meehl et al. (2006) found that under strong greenhouse forcing, the PCM and CCSM3 coupled models both featured significantly decreased ENSO amplitude, attributable to the warmer but more diffuse thermocline, in turn related to reduced wind driven meridional overturning cells in the upper ocean. Thus, the response of ENSO variability to increased greenhouse gas forcing is model dependent.

As shown in Table V, El Niño amplitude measured as the standard deviation of the Niño-3 index increases under $2 \times \mathrm{CO}_{2}$ in both model versions. This is consistent with the increased vertical intensification of the thermocline described in section 3. Increased ENSO variability, when coupled through the atmospheric teleconnection, would provide for greater monsoon variability as witnessed in the previous section. However, other studies have shown the basic state in the Pacific itself to influence monsoon variability. Meehl and Arblaster (2003) simulated future greenhouse warming scenarios by imposing fixed warm SST anomalies across the Pacific basin upon a dataset of observed SSTs forcing an atmosphere-only GCM. Stronger interannual variation of the monsoon was noted in their experiment, the warmer basic state causing greater variations in latent heat flux variability to be transmitted via the Walker circulation to the monsoon. In

Table V. SST anomaly amplitude $(\sigma)$ of the Niño-3 region. Units are ${ }^{\circ} \mathrm{C}$.

\begin{tabular}{lccc}
\hline $\mathrm{CO}_{2}$ & HadCM3 & HadCM3IPFA & ERA-40 \\
\hline Observed & - & - & 0.85 \\
$1 \times \mathrm{CO}_{2}$ & 0.94 & 1.21 & - \\
$2 \times \mathrm{CO}_{2}$ & 1.05 & 1.32 & - \\
\hline
\end{tabular}

this model framework, this hypothesis is tested by taking correlations between monsoon variability (the standard deviation of the DMI), Pacific variability (Niño-3 SST anomaly standard deviation) and Pacific mean temperatures (Niño-3 mean SST). Each is measured through an 11-year moving window. These correlations are shown for the Niño-3 region in Table VI, which indicates that on decadal timescales at least, correlations between monsoon variability and mean SST in the Pacific are insignificant when compared to correlations with Pacific SST variability. The same result is found if the Niño-3.4 or Niño-4 regions are used instead.

Figure 7 shows the timeseries of Niño-3 SST anomalies in both models at $2 \times \mathrm{CO}_{2}$. In HadCM3, behaviour seems reasonable, encompassing interspersed small and large El Niño-La Niña events separated by a range of periods. This integration shares similar characteristics to $1 \times \mathrm{CO}_{2}$ data and observations (not shown). In HadCM3IPFA, however, distinct regimes are present, encompassing a noticeable biennial tendency also evident in the monsoon (Figure 4). It is of interest that the biennial tendency of the monsoon-ENSO system in HadCM3IPFA is also present in some other IPCC AR4 models (Nanjundiah et al., 2005). These regimes and the tendency of the model ENSO to oscillate at a higher frequency will be discussed in part II of this paper.

\section{The changing monsoon-ENSO teleconnection}

\subsection{Mean relationship}

Despite the predicted increase in mean monsoon precipitation, the projected increased interannual variability will place new demands on managing socio-economic impacts. Thus it is now pertinent to consider the monsoon-ENSO teleconnection in these future climate scenarios, and whether predictability on seasonal to interannual timescales will change. Figure 8 shows the 
Table VI. Correlations between monsoon strength and mean Pacific SST or variability in 11-year window.

Above $\sim 0.6$ correlations are significant at the $95 \%$ level.

\begin{tabular}{lcccc}
\hline Correlation & $\mathrm{HadCM} 3$ & $\mathrm{HadCM} 3 \mathrm{IPFA}$ & $\mathrm{HadCM}$ & $\mathrm{HadCM} 3 \mathrm{IPFA}$ \\
& $1 \times \mathrm{CO}_{2}$ & $1 \times \mathrm{CO}_{2}$ & $2 \times \mathrm{CO}_{2}$ & $2 \times \mathrm{CO}_{2}$ \\
\hline$\sigma(\mathrm{DMI})$ vs. mean(Niño-3) & -0.13 & -0.13 & -0.08 & -0.09 \\
$\sigma(\mathrm{DMI})$ vs. $\sigma($ Niño-3) & 0.80 & 0.88 & 0.86 & 0.93 \\
\hline
\end{tabular}
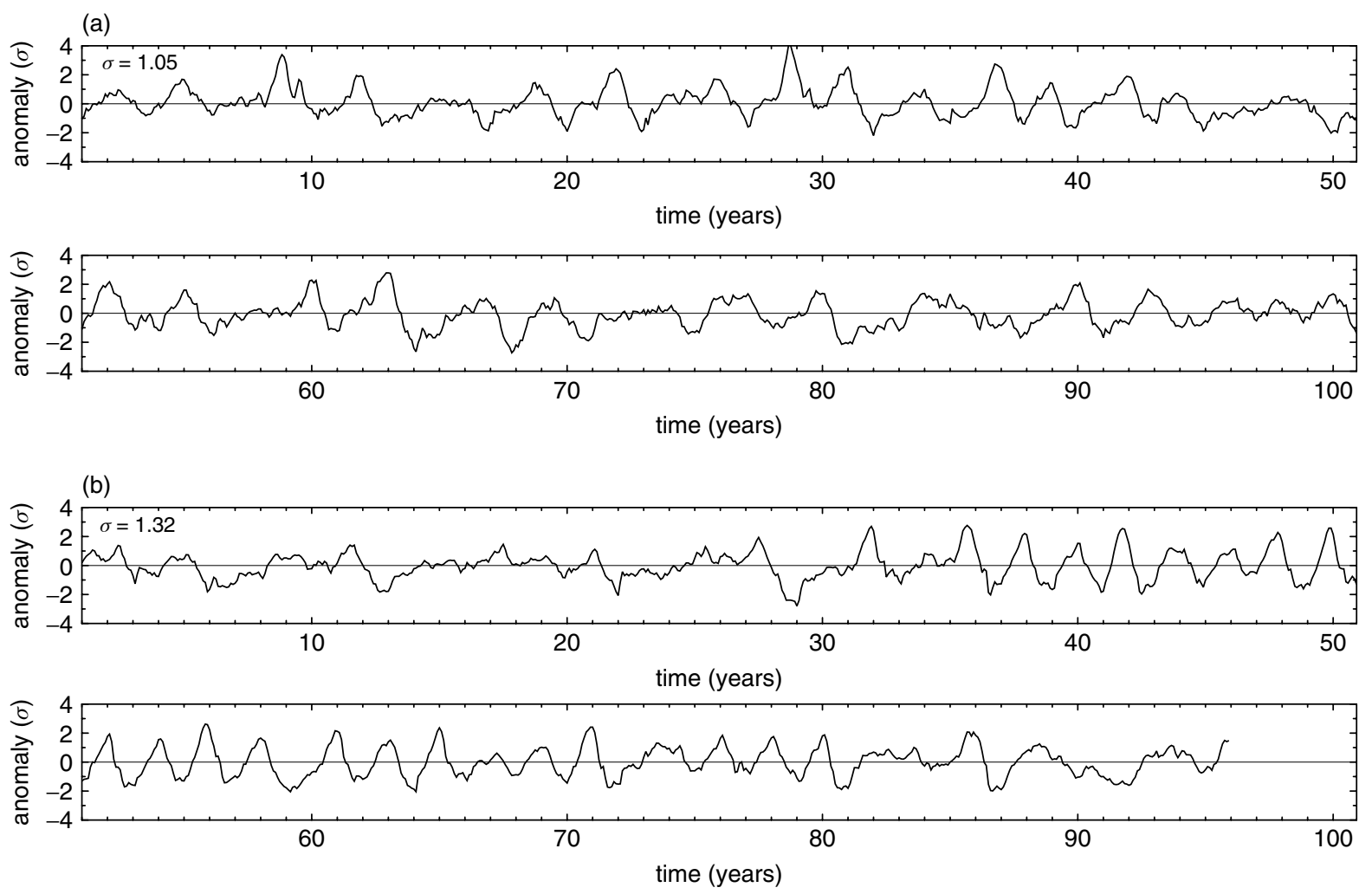

Figure 7. Normalized timeseries of Niño-3 SST anomalies at $2 \times \mathrm{CO}_{2}$ for (a) HadCM3 and (b) HadCM3IPFA.

lag-correlations between Niño-3 SST anomalies and the DMI and Indian Rainfall. Looking first at monsoon dynamics (Figure 8(a)), the teleconnection is strengthened under climate change in both versions of the model, suggesting that the Asian summer monsoon may become more predictable under $2 \times \mathrm{CO}_{2}$ conditions. In HadCM3, the timing of the Niño-3 teleconnection maximum is later and comparable to present day reanalysis. Looking at the rainfall relation in Figure 8(b), however, the impact of climate change is less obvious. The HadCM3 teleconnection seems to weaken, whereas in HadCM3IPFA it stays at broadly the same strength during the summer and autumn. Ashrit et al. (2003) found no systematic change to the monsoon-ENSO teleconnection in their transient climate change study; indeed, they noted the Niño-3 relation with the DMI to be quite robust, consistent with our study. Other indices however, such as meridional wind shear over the Indian sector, were less stable. In their study of the observed east Pacific SST and Indian rainfall records, Torrence and Webster (1999) found high coherence between the two regions during periods of high ENSO and high monsoon variability. This is confirmed by our strengthened dynamical teleconnections during $2 \times \mathrm{CO}_{2}$ forcing, concurrent with enhanced variability in both sectors. Indeed $\mathrm{Hu}$ et al. (2000) also noticed increased ENSO variability in a transient simulation of a future climate, connected to higher monsoon variability.

One can also verify the effect of flux adjustments alone on the teleconnection. Figure 8 demonstrates that systematic biases in the equatorial oceans have a much more significant impact on the strength of the monsoonENSO teleconnection than increased greenhouse forcing. Considering the composite evolution of equatorial Pacific SSTs during El Niño events from each of the future climate scenarios (not shown), the same argument holds as in the $1 \times \mathrm{CO}_{2}$ integrations. Flux adjustments shift the warmest waters further east, repositioning the ascending branch of the Pacific Walker circulation such that ENSO anomalies are more easily communicated from the Niño-3 region, strengthening the teleconnection in HadCM3IPFA (see TIS05).

The teleconnections of the HadCM3IPFA $2 \times \mathrm{CO}_{2}$ integration in Figure 8 exhibit an interesting property 

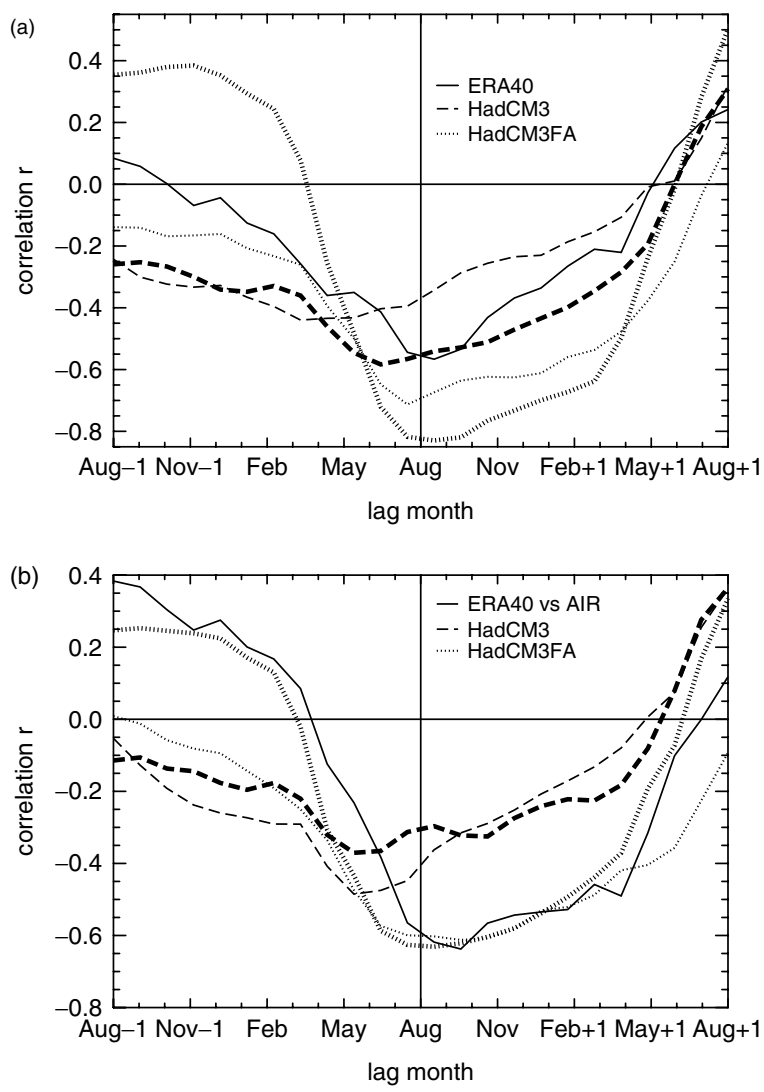

Figure 8. Correlation between Niño-3 SST and summer (JJAS) (a) DMI or (b) Indian rainfall plotted against lag time. In (b), ERA40 vs AIR refers to the All-India Rainfall precipitation data being correlated with ERA-40 SSTs. Correlations are significant in all but $5 \%$ of cases when $|r|>0.31$ for observations, $|r|>0.2$ for model integrations. Thin (thick) lines are $1 \times \mathrm{CO}_{2}\left(2 \times \mathrm{CO}_{2}\right)$.

prior to monsoon development, with strong positive correlations at lead times of 12 to 5 months, reaching +0.4 for the DMI and +0.25 for Indian rainfall. These suggest that east Pacific warmings during one summer are followed by strong Asian monsoons the next, consistent with correlations in the observed data. The strong biennial component to monsoon and ENSO variability (Figures 4 and 7 respectively) is thus evident in the teleconnection, although when periods of biennial ENSO variation are removed from the data, the dynamical teleconnection is still stronger during JJAS than in HadCM3IPFA $1 \times$ $\mathrm{CO}_{2}$ whereas the rainfall teleconnection is weakened. Variations in the monsoon-ENSO system under different ENSO regimes will be shown in part II of this paper.

\subsection{Interdecadal relationship}

Recent weakening of the monsoon-ENSO relationship in the observed record raises interesting questions for monsoon prediction. Indeed the 1997-98 El Niño was the largest on record, yet a normal monsoon prevailed over India, the country receiving $102 \%$ of the seasonal average rainfall (Slingo and Annamalai, 2000). Whilst there is some evidence to suggest that the recent weakening is associated with anthropogenic influences (e.g. Krishna
Kumar et al., 1999) this is by no means certain and does not explain earlier changes in the record.

The change in teleconnection strength may also relate to changes in observed ENSO modal behaviour occurring over the same period. Indeed Slingo and Annamalai (2000) suggest that very strong El Niños such as 1997 may lead to different wind regimes acting on the monsoon system, modulating the local Hadley circulation in such a way as to favour strong monsoon conditions. Some recent studies (e.g. Annamalai and Liu, 2005) note that El Niño events during different periods (before and after 1976) have quite a different impact on the monsoon. Others, such as Annamalai et al. (2007), which includes more recent observations, suggest that the relationship between El Niño and the monsoon may be strengthening again. The authors cite the deficient monsoons of $2002(-19 \%)$ and $2004(-13 \%)$ during moderate Pacific warmings.

To explore interdecadal changes in ENSO-monsoon teleconnections, moving correlations for summer monsoon statistics versus Niño-3 timeseries are shown for all model integrations in Figure 9. Most noticeable is the large variation in teleconnection strength through each integration, despite fixed $\mathrm{CO}_{2}$ concentrations. Correlations are rarely significant using either monsoon measure
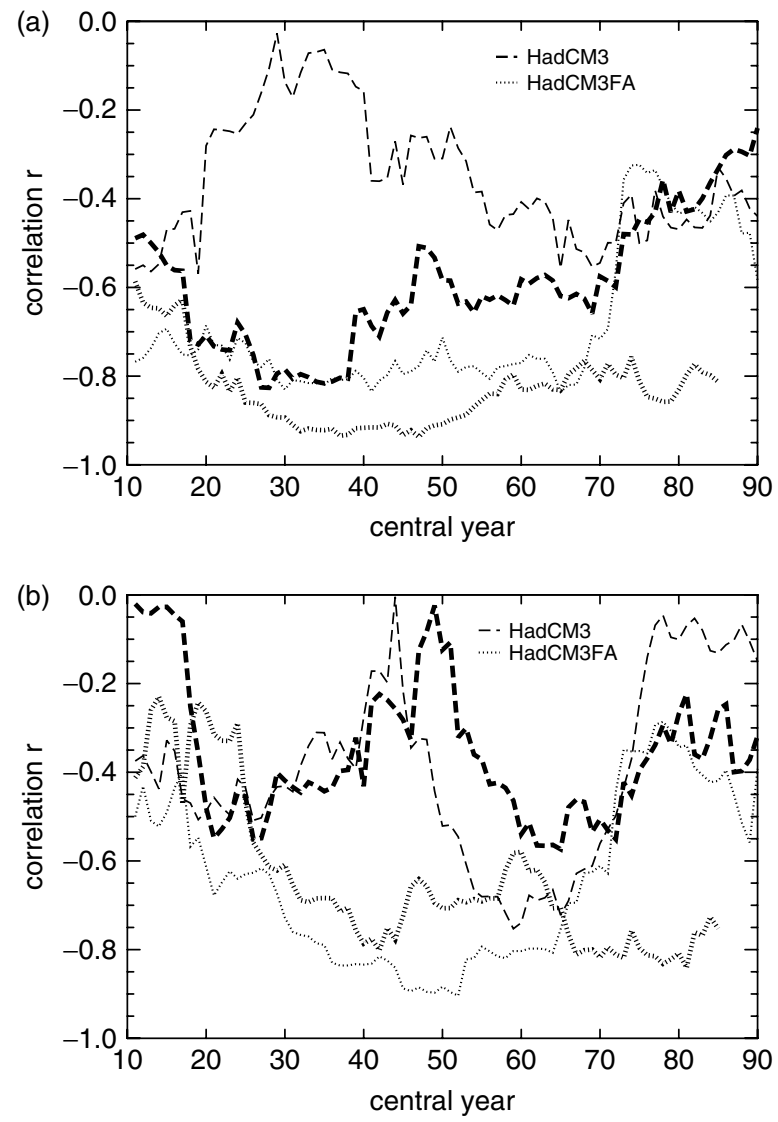

Figure 9. 21-year moving instantaneous correlation between summer (JJAS) Niño-3 region SSTs and (a) DMI or (b) Indian rainfall in HadCM3 and HadCM3IPFA integrations at $1 \times \mathrm{CO}_{2}$ and $2 \times \mathrm{CO}_{2}$. Correlations are significant in all but $5 \%$ of cases when $r<-0.43$. Thin (thick) lines are for $1 \times \mathrm{CO}_{2}\left(2 \times \mathrm{CO}_{2}\right)$ integrations. 
in the $\mathrm{HadCM} 31 \times \mathrm{CO}_{2}$ integration due to poor representation of the basic state (TIS05). In the flux-adjusted models (at $1 \times \mathrm{CO}_{2}$ and $2 \times \mathrm{CO}_{2}$ ) there is much greater correspondence between the strengths of dynamic and rainfall correlations as noted in Table IV.

The stability of teleconnections over the entirety of model integrations has also been studied by Annamalai et al. (2007). These authors used twentieth century $\mathrm{CO}_{2}$ forcing simulations of the IPCC AR4 models and found the GFDL_ CM_ 2.0, GFDL_ CM_ 2.1 and MRI models to have a range of correlation variation similar to that observed. The moving teleconnections did not match the phase changes seen in observations however, with no noticeable weakening trend. This suggests that climate change may not be the cause of recent weakening in the teleconnection (as suggested by some authors e.g. Krishna Kumar et al., 1999; Ashrit et al., 2005). Indeed whilst recent observed monsoon-ENSO teleconnections seem to have declined, the modelled climate change response has been one of a generally robust relationship (in this and other studies). Ashrit et al. (2003) also suggest that recent weakening is more likely related to internal variability of the monsoon-ENSO system. Our study therefore confirms the view that internal variability has a more significant impact on changing monsoonENSO teleconnections than climate change.

\section{Conclusions}

The doubling of carbon dioxide concentration in HadCM3 has had several impacts on the mean climate of the coupled Indo-Pacific system. A slight northward shift in the Somali Jet, accompanied by significant increases in seasonal precipitation in the Asian summer monsoon region, amounts to an increase in mean monsoon strength. The increased monsoon precipitation is due to increased moisture convergence over the warmer Indian Ocean, and occurs despite the effects of El Niño-like warming in the tropical Pacific Ocean. There are also significant and consistent increases in precipitation in the Pacific ITCZ from the Philippines to $120^{\circ} \mathrm{W}$. The system of limitedarea flux adjustments affect the mean climate in the same way as under $1 \times \mathrm{CO}_{2}$ conditions, although the response to greenhouse gas increase in HadCM3IPFA is stronger in all mean fields, with an increase of nearly $13 \%$ in monsoon precipitation. This illustrates the fundamental importance of reproducing the correct basic state conditions in the coupled system.

The subsurface response to $\mathrm{CO}_{2}$ doubling bears a signature of the El Niño-like surface change, resulting in an increased vertical gradient of the thermocline. This contributes to increased SST variability in the east Pacific, a fundamental component of ENSO. Interannual variability of the monsoon increases at $2 \times \mathrm{CO}_{2}$, and rises further with flux adjustments, when the monsoon also exhibits strong biennial behaviour.

Monsoon dynamics are increasingly predictable when using ENSO indicators in the future climate, and the monsoon precipitation teleconnection to the east Pacific remains generally robust. A consequence of this is the increased correspondence between monsoon dynamics and precipitation at $2 \times \mathrm{CO}_{2}$, although the complex relationship between monsoon precipitation and dynamics in GCMs deserves further scrutiny. The flux-adjusted model sees a stronger monsoon-ENSO teleconnection using both measures, as under $1 \times \mathrm{CO}_{2}$. This demonstrates the significant impact of model bias on monsoon predictability, an impact greater than climate change itself. The monsoon-ENSO teleconnection is found however to undergo variations on interdecadal timescales, despite the absence of transient external forcing. These variations are of similar amplitude to those in observations and thus changes to the mean teleconnection due to systematic errors or increased greenhouse forcing may lie within this range. Hence, there is still much to understand about interdecadal and climatic changes in the coupled monsoon-ENSO system, which may require much longer GCM integrations to be performed.

The pre-season biennial character to the monsoonENSO teleconnections in HadCM3IPFA, which indicates the crucial link between the biennial monsoon variability and biennial ENSO in HadCM3IPFA at $2 \times \mathrm{CO}_{2}$, will be further explored in part II of this paper.

\section{Acknowledgements}

A. G. Turner was supported through a $\mathrm{PhD}$ studentship provided by NERC's National Centre for Atmospheric Science (NCAS), and is now funded via the EUENSEMBLES project. Julia Slingo and Pete Inness are members of NCAS, Pete Inness being partially funded by the EU-DYNAMITE project. The authors wish to thank the Associate Editor Richard Seager, Jerry Meehl, and a further anonymous reviewer who have provided useful comments which helped improve this manuscript. In addition we are grateful to Jason Lowe of the Hadley Centre Atmosphere for providing atmosphere and ocean start dumps; the British Atmospheric Data Centre for supplying the ERA-40 dataset; The Climate Prediction Center for CMAP data; the Indian Institute of Tropical Meteorology, Pune, for their All-India Rainfall. Computing resources were provided by CSAR for running the Unified Model.

\section{References}

Annamalai H, Hamilton K, Sperber, KR. 2007. The South Asian Summer Monsoon and Its Relationship with ENSO in the IPCC AR4 Simulations. J. Climate, 20: 1071-1092 DOI: 10.1175/JCLI4035.1. Annamalai H, Liu P. 2005. Response of the Asian summer monsoon to changes in El Niño properties. Q. J. R. Meteorol. Soc. 131: 805-831. DOI: $10.1256 /$ qj.04.08.

Ashrit R, Douville H, Kumar K. 2003. Response of the Indian Monsoon and ENSO-monsoon teleconnections to enhanced greenhouse effect in the CNRM coupled model. J. Meteorol. Soc. Jpn 81: 779-803. doi:10.2151/jmsj.81.779.

Ashrit RG, Kitoh A, Yukimoto S. 2005. Transient Response of ENSO-Monsoon Teleconnection in MRI-CGCM2.2 Climate 
Change Simulations. J. Meteorol. Soc. Jpn 83: 273-291. doi: $10.2151 /$ jmsj.83.273.

Collins M. 2000a. The El Niño-Southern Oscillation in the Second Hadley Centre Coupled Model and Its Response to Greenhouse Warming. J. Climate 13: 1299-1312. DOI: 10.1175/15200442(2000)013<1299:TENOSO > 2.0.CO;2.

Collins M. 2000b. Understanding uncertainties in the response of ENSO to greenhouse warming. Geophys. Res. Lett. 27: 3509-3512.

Collins M and The CMIP Modelling Groups. 2005. El Niño- or La Niña-like climate change?. Clim. Dyn. 25: 89-104.

Federov AV, Philander S G. 2000. Is El Niño Changing? Science 288: 1997-2002. DOI: 10.1126/science.288.5473.1997.

Gadgil S, Sajani S. 1998. Monsoon precipitation in the AMIP runs. Clim. Dyn. 14: 659-689. DOI: 10.1007/s003820050248.

Gordon C, Cooper C, Senior CA, Banks H, Gregory JM, Johns TC, Mitchell JFB, Wood R A. 2000. The simulation of SST, sea ice extents and ocean heat transports in a version of the Hadley Centre coupled model without flux adjustments. Clim. Dyn. 16: 147-168. DOI: $10.1007 / \mathrm{s} 003820050010$.

Guilyardi E. 2006. El Niño - mean state - seasonal cycle interactions in a multi-model ensemble. Clim. Dyn. 26: 329-348. DOI: 10.1007/s00382-005-0084-6.

Hu Z-Z, Latif M, Roeckner E, Bengtsson L. 2000. Intensified Asian summer monsoon and its variability in a coupled model forced by increasing greenhouse gas concentrations. Geophys. Res. Lett. 27: 2618-2684.

Intergovernmental Panel on Climate Change. 2001. Climate Change 2001: The scientific basis. Contribution of Working Group I to the Third Assessment Report, Houghton JT, Ding Y, Griggs DJ, Noguer M, van der Linden PJ, Dai X, Maskell K, Johnson CA (Eds). Cambridge University Press: UK.

Inness PM, Slingo JM, Guilyardi E., Cole J. 2003. Simulation of the Madden-Julian Oscillation in a coupled general circulation model. Part II: The role of the basic state. J. Climate 16: 365-382. DOI: 10.1175/1520-0442(2003)016<0365:SOTMJO > 2.0.CO;2.

Inness PM, Slingo JM, Woolnough S, Neale R, Pope V. 2001. Organization of tropical convection in a GCM with varying vertical resolution: Implications for the simulation of the Madden-Julian Oscillation. Clim. Dyn. 17: 777-793. DOI: 10.1007/s003820000148.

Johns TC, Gregory JM, Ingram WJ, Johnson CE, Jones A, Lowe JA, Mitchell JFB, Roberts DL, Sexton DMH, Stevenson DS, Tett SFB, Woodage MJ. 2003. Anthropogenic climate change for 1860 to 2100 simulated with the HadCM3 model under updated emissions scenarios. Clim. Dyn. 20: 583-612. DOI: 10.1007/s00382-002-0296y.

Kitoh A, Yukimoto S, Noda A, Motoi T. 1997. Simulated Changes in the Asian Summer Monsoon at Times of Increased Atmospheric $\mathrm{CO}_{2}$. J. Meteorol. Soc. Jpn 75: 1019-1031.

Krishna Kumar K, Rajagopalan B, Cane M A. 1999. On the Weakening Relationship Between the Indian Monsoon and ENSO. Science 284: 2156-2159. DOI: 10.1126/science.284.5423.2156.

Latif M, Sperber K, Arblaster J, Braconnot P, Chen D, Colman A, Cubasch U, Cooper C, Delecluse P, DeWitt D, Fairhead L, Flato G, Hogan T, Ji M, Kimoto M, Kitoh A, Knutson T, Le Treut H, Li T, Manabe S, Marti O, Mechoso C, Meehl G, Power S, Roeckner E, Sirven J, Terray L, Vintzileos A, Voss R, Wang B, Washington W, Yoshikawa I, Yu J, Zebiak S. 2001. ENSIP: the El Niño simulation intercomparison project. Clim. Dyn. 18: 255-276. DOI: $10.1007 / \mathrm{s} 003820100174$.

Martin GM, Arpe K, Chauvin F, Ferranti L, Maynard K, Polcher J, Stephenson DB, Tschuck P. 2000. Simulation of the Asian Summer Monsoon in Five European General Circulation Models. Atmos. Sci. Let. 1: 37-55. DOI: 10.1006/asle.2000.0004.

May W. 2004. Potential future changes in the Indian summer monsoon due to greenhouse warming: analysis of mechanisms in a global timeslice experiment. Clim. Dyn. 22: 389-414. DOI: 10.1007/s00382003-0389-2.

Meehl G A. 1997. The South Asian Monsoon and the Tropospheric Biennial Oscillation. J. Climate 10: 1921-1943. DOI: 10.1175/15200442(1997)010<1921:TSAMAT > 2.0.CO;2.

Meehl GA, Arblaster J M. 2003. Mechanisms for projected future changes in south Asian monsoon precipitation. Clim. Dyn. 21: 659-675. DOI: 10.1007/s00382-003-0343-3.

Meehl GA, Collins WD, Boville BA, Kiehl JT, Wigley TML, Arblaster J M. 2000. Response of the NCAR climate system model to increased $\mathrm{CO}_{2}$ and the role of physical processes. J. Climate 13: 1879-1898. DOI: $10.1175 / 1520-0442(2000) 013<1879$ :ROTNCS $>2.0 . C O ; 2$.
Meehl GA, Tang H, Branstator G. 2006. Future changes of El Niño in two coupled climate models. Clim. Dyn. 26: 549-566. DOI: 10.1007/s00382-005-0098-0.

Meehl GA, Washington W M. 1993. South Asian Summer Monsoon Variability in a Model with Doubled Atmospheric Carbon Dioxide Concentration. Science 260: 1101-1104. DOI: 10.1126/science.260.5111.1101.

Meehl GA, Washington W M. 1996. El Niño-like climate change in a model with increased atmospheric $\mathrm{CO}_{2}$ concentrations. Nature 382: 56-60. doi:10.1038/382056a0.

Merryfield W J. 2006. Changes to ENSO under $\mathrm{CO}_{2}$ Doubling in a Multimodel Ensemble. J. Climate 19: 4009-4027. DOI: 10.1175/JCLI3834.1.

Nanjundiah RS, Vidyunmala V, Srinivasan J. 2005. The impact of increase in $\mathrm{CO}_{2}$ on the simulation of tropical biennial oscillations (TBO) in 12 coupled general circulation models. Atmos. Sci. Let. 6 : 183-191. DOI: 10.1002/asl.115.

Ogasawara N, Kitoh A, Yasunari T, Noda A. 1999. Tropospheric Biennial Oscillation of ENSO-Monsoon System in the MRI Coupled GCM. J. Meteorol. Soc. Jpn 77: 1247-1270.

van Oldenborgh GJ, Philip S, Collins M. 2005. El Niño in a changing climate: A multi-model study. Ocean Sci. Discuss. 2: 267-298.

Parthasarathy B, Munot AA, Kothawale D R. 1994. All-India Monthly and Seasonal Rainfall Series: 1871-1993. Theor. Appl. Climatol. 49: 217-224. DOI: 10.1007/BF00867461.

Pope VD, Gallani ML, Rowntree PR, Stratton R A. 2000. The impact of new physical parametrizations in the Hadley Centre climate model: HadAM3. Clim. Dyn. 16: 123-146. DOI: 10.1007/s003820050009.

Rayner NA, Parker DE, Horton EB, Folland CK, Alexander LV, Rowell DP, Kent EC, Kaplan A. 2003. Global analyses of sea surface temperature, sea ice, and night marine air temperature since the late nineteenth century. J. Geophys. Res. 108(D14): 4407, doi:10.1029/2002JD002670.

Slingo JM, Annamalai H. 2000. 1997: The El Niño of the Century and the Response of the Indian Summer Monsoon. Mon. Weather Rev. 128: 1778-1797. DOI: 10.1175/15200493(2000)128<1778:TENOOT > 2.0.CO;2

Spencer H, Slingo J M. 2003. The simulation of peak and delayed ENSO teleconnections. J. Climate 16: 1757-1774. DOI: 10.1175/1520-0442(2003)016<1757:TSOPAD > 2.0.CO;2.

Sperber KR, Palmer T N. 1996. Interannual tropical rainfall variability in general circulation model simulations associated with the atmospheric model intercomparison project. J. Climate 9: 2727-2750. DOI: 10.1175/1520-0442(1996)009<2727:ITRVIG > 2.0.CO;2.

Sutton RT, Dong B, Gregory JM. 2007. Land/sea warming ratio in response to climate change: IPCC AR4 model results and comparison with observations. Geophys. Res. Lett. 34: L02701. doi:10.1029/2006GL028164.

Timmermann A, Oberhuber J, Bacher A, Esch M, Latif M, Roeckner E. 1999. Increased El Niño frequency in a climate model forced by future greenhouse warming. Nature 398: 694-697. doi:10.1038/19505.

Timmermann A, Jin F-F, Collins M. 2004. Intensification of the annual cycle in the tropical Pacific due to greenhouse warming. Geophys. Res. Lett. 31: L12208. doi:10.1029/2004GL019442.

Torrence C, Webster P J. 1999. Interdecadal changes in the ENSOmonsoon system. J. Climate 12: 2679-2690. DOI: 10.1175/15200442(1999)012<2679:ICITEM > 2.0.CO;2.

Turner AG, Inness PM, Slingo J M. 2005. The role of the basic state in the ENSO-monsoon relationship and implications for predictability. Q. J. R. Meteorol. Soc. 131: 781-804. DOI: 10.1256/qj.04.70.

Turner AG, Inness PM, Slingo J M. 2007. The effect of doubled $\mathrm{CO}_{2}$ and model basic state biases on the monsoon-ENSO system. II: Changing ENSO regimes. Q. J. R. Meteorol. Soc., In press. DOI: 10.1002/qj.83.

Uppala SM, Kallberg PW, Simmons AJ, Andrae U, da Costa Bechtold V, Fiorino M, Gibson JK, Haseler J, Hernandez A, Kelly GA, Li X, Onogi K, Saarinen S, Sokka N, Allan RP, Andersson E, Arpe K, Balmaseda MA, Beljaars ACM, van de Berg L, Bidlot J, Bormann N, Caires S, Chevallier F, Dethof A, Dragosavac M, Fisher M, Fuentes M, Hagemann S, Holm E, Hoskins BJ, Isaksen L, Janssen P A E M, Jenne R, McNally AP, Mahfouf J -F, Morcrette J -J, Rayner NA, Saunders RW, Simon P, Sterl A, Trenberth KE, Untch A, Vasiljevic D, Viterbo P, Woollen J. 2005. The ERA-40 re-analysis. $Q . J . R$ Meteorol. Soc. 131: 2961-3012. DOI: 10.1256/qj.04.176.

Webster PJ, Yang S. 1992. Monsoon and ENSO: Selectively interactive systems. Q. J. R. Meteorol. Soc. 118: 877-926. DOI: 10.1002/qj.49711850705 
Webster PJ, Magana VO, Palmer TN, Shukla J, Tomas RA, Yanai M, Yasanuri T. 1998. Monsoons: Processes, predictability, and prospects for prediction. J. Geophys. Res. 103: 14451-14 510. DOI: 10.1029/97JC02719.
Xie P, Arkin P A. 1997. Global Precipitation: A 17-Year Monthly Analysis Based on Gauge Observations, Satellite Estimates, and Numerical Model Outputs. Bull. Am. Meteorol. Soc. 78: 2539-2559. DOI: 10.1175/1520-0477(1997)078<2539:GPAYMA>2.0.CO;2. 